\title{
GEORGE BERKELEY AND MOTOORI NORINAGA ON OTHER MINDS AND THERE BEING "NOTHING TO BE DONE"
}

\author{
WUNG CHENG CHIM
}

\begin{abstract}
The 18th century Irish philosopher George Berkeley argued that we might know of the existence of other minds based upon our experience of having certain sense-data or "ideas" imprinted upon us. This served, for Berkeley, ultimately as a basis for us to know of a "grand" other mind orchestrating the order among said ideas imprinted upon us, that is, God. This leap to God, however, has been challenged over the past three decades. A very rudimentary form could still be retained though from Berkeley's argument for God, whereby Berkeley argued that human minds were dependent upon other "more powerful" minds. I shall open with the contention that Berkeley did not actually show that there must exist one or many other minds orchestrating the order among imprinted ideas. This contention shall serve as the ground for speculating what form Berkeleyanism would take, if we posit many other minds instead of one God. I shall argue that this Berkeleyanism "reworked" on the premise of many other minds, could understand those ideas imprinted upon us as having been decided by a commune of finite other minds. I shall also argue that the experience of having ideas imprinted upon us is identical to an experience the Japanese thinker of the same century, Motoori Norinaga, expressed with the phrase semusubenaki ("There is nothing to be done"). This experience of there being "nothing-to-be-done" (Nasusubenaki) shall also be situated within the Berkeleyanism "reworked" around the premise of a commune of other minds imprinting ideas upon us to speculative ends.
\end{abstract}

Keywords: George Berkeley, Motoori Norinaga, problem of other minds

\section{INTRODUCTION}

I aim to examine here George Berkeley's treatment of other minds, chiefly that in passages 28-33, in his Principles of Human Knowledge, in conjunction with a term used by Motoori Norinaga and analyzed by Sagara Tōru (1978) in his commentaries on Norinaga, semusubenaki. By the end of this article, I hope to have offered a preliminary sketch for a "reworking" of Berkeleyanism centered around our relation to other "more powerful" minds. At the same time, this "reworked" Berkeleyanism would

CHIM, WUNG CHENG (詹弘鉹) is a PhD candidate at the Department of English in the Chinese University of Hong Kong, Hong Kong, China. Email: raphaelchim@link.cuhk.edu.hk 
also be a secular one whereby the world is no longer produced and organized by one God, but by a commune of numerous other minds. I shall further demonstrate a semblance between Berkeley's treatment of other minds and the relation prescribed by Norinaga between human beings and gods, but where Berkeley did not make clear the exact human experience of our relation to other minds, Norinaga expressed it clearly with the phrase, "there is nothing to be done" (semusubenashi). I shall thus draw upon Norinaga to complete this "reworked" Berkeleyanism by identifying the human experience in our relation to other minds as that of "nothing-to-be-done" (Nasusubenaki).

It must be noted though that, due to their preoccupations with the divine and its role in bringing about beings and events in the world, Berkeley and Norinaga's writings were intensely religious, often apologetic. Berkeley's (1967b, 55) treatment of other minds, especially, took a sharp theological turn and concluded in the existence of another mind "more powerful" than us. That said, over the past three decades, we have seen attempts to "secularize" Berkeley, so to speak. Challenges have been posed to Berkeley's leap to this other "more powerful" mind in the likeness of God. Two attempts have been made by Margaret Atherton (1995) and Helen Yetter-Chappell (2017) in working out a Berkeleyanism without God. Ekaterina Ksenjek and Daniel Flage (2012) have likewise argued that the passages I would be considering here did not necessarily force us to acknowledge a God in the singular, much less a JudeoChristian God. Although there was no taking Christianity away from Bishop Berkeley, we can now see the hope of "secularizing" Berkeleyanism, so to speak. I would like to take the works of Atherton, Yetter-Chappell, Ksenjek, Flage, among others as my cue and further rework Berkeley's treatment of God into a more "secular" treatment of other minds in general.

To this end, I would like to draw also upon the Shinto-inspired ontology of Motoori Norinaga. Norinaga, as a thinker, did not enjoy a particularly intimate relation with others. If we are to look for a treatment of other minds in his writings, we might immediately find his harsh attacks on what he called "Chinese minds" (karagokoro) ${ }^{1}$ (see, for one instance, Norinaga 1991, 30 for his contrasting of the minds of the ancient Japanese and the Chinese). It is certainly an inescapable burden that we would be confronted with unsavory remarks on ethnic, cultural, etc. others, whilst contending with $18^{\text {th }}$ century thinkers. Instead of Norinaga's own treatment of the relations between ethnic, cultural, etc. others, however, I would like to consider his treatment of the relations between human beings and gods. This is not only for ease of comparison with Berkeley. Since Norinaga $(1930,4)$ believed in ethnic and cultural spheres which were originally self-contained ${ }^{2}$, I think it safe for us to think that, for Norinaga, the

\footnotetext{
${ }^{1}$ See also Antoni 2004, for an examination of the treatments of the term "Chinese mind" by other native studies thinkers, as well as its ties to $20^{\text {th }}$ century fascism in Japan.

${ }^{2}$ Norinaga maintained that the significations, events, and expressions of each age and locale was contained to itself (Motoori 1930, 4). This was the basis by which he chose to commentate on the Kojiki, instead of the other historical and mythical record, the Nihonshoki, which he held to have been too dependent on the style of Chinese texts and was, hence, no longer faithful to the events it was meant to record.
} 
chief of the other minds, to whom human beings might relate, were not the minds of human beings outside the sphere, but the native ones shaping the spheres.

Like Berkeley though, Norinaga was not entirely without his "secular" moments. Sagara Tōru $(1978,54)$ has argued that Norinaga maintained a divide between the individual world of poetics and the social world of teachings throughout his life. If we follow Sagara in arguing so, we may say Norinaga preserved a safety zone for a secular feudal subject away from the reign and worship (matsurigoto) of the deified monarch and shoguns acting as proxies of monarchs. In the $21^{\text {st }}$ century, the monogaku (lit. "the study of things") movement has also begun using elements of Norinaga's thoughts in more secular contexts. For one, the creative deity (or deities) central to Norinaga's theology, the Musubi no Kami, has been used by Kamata Tōji $(2009,9)$ as the name for a "force" allowing for the interiorization of ordinary objects. ${ }^{3}$

This article shall aim to offer a completely "secular" reading of both Berkeleyanism (as presented in Principles of Human Knowledge) and Norinaga's Shinto cosmology. Section 2 shall begin by examining passages 28 to 33 from Principles of Human Knowledge, where Berkeley was said to have not only showed how we derived knowledge of other minds, but also our knowledge of God. This knowledge of God, however, has been challenged by Margaret Atherton, Helen Yetter-Chappell, and Ekaterina Ksenjek and Daniel Flage. By surveying these challenges, I would ease the way into Section 3 where I would attempt to "rework" the Berkeleyan knowledge of other minds by emphasizing on Berkeley's characterization of said minds as being "more powerful", after which I would also speculate as to what it would mean to have numerous other minds at work instead of the singular other mind Berkeley opted for. Section 4 shall proceed into Motoori Norinaga's cosmology. I shall argue that Norinaga, like Berkeley, also placed much emphasis on the experience of having something given to us and was responding to this experience when he wrote, "There is nothing I can do" (semusubenashi). In this section, I shall also propose that the expression, "There is nothing I can do", must come after a prior experience I shall denote as "nothing-to-bedone" (Nasusubenaki). Section 5 shall also compare Berkeley and Norinaga and argued that they concurred on the points that something was given to/imprinted upon us; and that if a being was held responsible for giving to/imprinting upon us something, then this being must also be "more powerful" than us. This final section would also attempt to situate the experience of "nothing-to-be-done" within the Berkeleyanism "reworked" in section 3 .

\footnotetext{
${ }^{3}$ I refer to the Musubi no Kami as an element of Norinaga's thoughts, since Isomae Jun'ichi (2000, 24) has argued that Norinaga's interpretation of the Musubi no Kami as "the fundamental source of all beings" was actually a departure from the Kojiki which Norinaga was interpreting, where the Musubi no Kami were only names within "an enumeration of the names of kami". Hence, theologies and cosmologies where the deities were given prominent roles, and contemporary uses of this deity's name influenced by the significance attributed to the deities within said theologies and cosmologies, would have to be traced back to Norinaga.
} 


\section{BERKELEY: PROBLEMS IN PASSAGE 28-33 OF PRINCIPLES OF HUMAN KNOWLEDGE}

As regards Berkeley, I would like to focus chiefly on the three passages quoted below (28-30) from Principles of Human Knowledge where Berkeley derived the knowledge of other minds from our experience of having ideas imprinted upon us. Subsequent passages (31-33) would also be referenced, though emphasis would remain on passages 28 to 30 which outlined clearly the sort of perceptual activities undertaken by our minds and the minds of others. I would begin by considering here the ordinary interpretation of these passages as a proof to establish the existence of God, after which I would move on to two challenges posed to this by Margaret Atherton (1995) and Helen YetterChappell (2017), as well as their own reworkings of Berkeleyanism based on the challenges they posed to Berkeley. However, I shall also note that these two reworkings did not inquire deeply enough into the causes of the order among imprinted ideas, which could lead to an incompatibility with our modern sensibilities which would understand finite minds to also serve a role in shaping the (specifically, natural) world. This would prompt a turn towards another challenge posed by Ekaterina Ksenjek and Daniel Flage (2012), which would serve as the basis for my own attempted "reworking" of Berkeleyanism.

"28. I find I can excite ideas in my mind at pleasure, and vary and shift the scene as oft as I think fit...

" 29 . When in broad day-light I open my eyes, it is not in my power to choose whether I shall see or no, or to determine what particular objects shall present themselves to my view...the ideas imprinted on them are not creatures of my will. There is therefore some other will or spirit that produces them...

" 30 . The ideas of sense are more strong, lively, and distinct than those of the imagination; they have likewise a steadiness, order, and coherence, and are not excited at random, as those which are the effects of human wills often are...the admirable connexion whereof sufficiently testifies the wisdom and benevolence of its Author." (Berkeley 1967b, 54)

From passage 28 to 29, we arrive at knowledge of the existence of some other mind which we hold to have produced those ideas unaccountable as our own. Passage 30 argues that this other mind must be qualitatively different from and superior to us on account of the steadiness, order, and coherence of those ideas it imprinted upon us. Unquoted here, passage 30 also begins to denote "the set rules or established methods, wherein the mind we depend[ed] on excite[d] in us the ideas of sense" the "Laws of Nature" (Berkeley 1967b, 54). By passage 33, the other mind exciting ideas in us has been given the name "Author of Nature" (55). Now since "Author of Nature" has an affinity with "one of the traditional names of the Judeo-Christian God", namely, "Creator of heaven and earth", while "wisdom" and "benevolence" attributed to this Author in passage 30 are also among "essential attributes of the Judeo-Christian God", these passages have been taken as presenting an argument to establish the existence of God (Ksenjek and Flage 2012, 285). 
To this common interpretation, we may ask whether it is necessary that we make the leap to God from the perceived order among ideas imprinted upon us. Margaret Atherton and Helen Yetter-Chappell both challenged this and put forth reinterpretations of Berkeleyanism which did away with God. Atherton (1995) argued that the attribution of the order among ideas to God could be separated from this order among ideas. Berkeley already contended a year prior to the publication of Principles of Human Knowledge, in An Essay towards a New Theory of Vision, that "we...ma[d]e sense of our experience because of its regular and orderly...nature", with this experience also being understood to be "distinct from and independent of $m y$ mind" (Atherton 1995, 243). In New Theory of Vision, however, he already substantiated his contention with "absolutely no reference to God" (232). The leap to God became a step tagged onto this pre-established theory of sensory perception and, therefore, omissible. YetterChappell $(2017,69)$ approached from another angle and argued that the "beliefs, desires, understanding, intentions" of God were unnecessary to sustaining order among ideas, and only God's "sensory experiences" which were "phenomenally unified", were required. She then argued that we could not only do away with God's personalities but also with God. This would leave us with a "phenomenal unity" which would be "independent from all finite minds", but also accessed by all finite minds: a unity consisting of the experiences of any object "from every possible perspective it might be viewed from...from every possible sort of perceiver" (Yetter-Chappell 2017, 69).

These two challenges and corresponding reworkings of Berkeleyanism offer us a glimpse of a secularized Berkeleyanism, but I think it necessary to note that both did not inquire deeply into the genesis of the imprinted ideas and the order perceived among them. This is particularly true in Yetter-Chappell's reworked Berkeleyanism. Her proposed phenomenal unity was something finite minds could only access, which was also independent of all these finite minds ${ }^{4}$. This, to my mind, has the risk of becoming incompatible with our $21^{\text {st }}$ century sensibilities which would assert firmly that we are responsible for the extreme climate conditions and other symptoms of the ongoing ecological crisis. Now, of course, we may say here that our influences on the natural world, however drastic, nevertheless obey certain basic Laws of Nature which would never bulge regardless of our efforts to change them, hence calling still for a measure of independence of the natural world from our minds. That said, it is also undeniable that there exist myriad particular, more complex rules of avian migration, seasonal weather transitions, etc. which are all susceptible to human and animal ${ }^{5}$ activities. Rather than doing away with God but leaving the creator(s) of the natural world ambivalent, I think we must take a step further by setting up finite other minds as participants in the production and organization of ideas imprinted upon us. To this end, I would like to turn to another challenge posed by Ksenjek and Flage to Berkeley's inference of God from the perceived order among imprinted ideas, for a hint as to how to "rework" Berkeleyanism in this direction.

${ }^{4}$ This is an inheritance from Berkeley who, as Atherton $(1995,244)$ noted, held that "the natural world [wa]s mind-dependent, but independent of any particular mind".

${ }^{5}$ Berkeley held that animals, like humans, likewise had minds, though minds which would render them "slaves of [their] passions", unlike the more sophisticated human minds (Charles 2010, 197). 
Unlike Atherton and Yetter-Chappell's challenges, Ksenjek and Flage questioned whether Berkeley even arrived at a conclusion in the Judeo-Christian God at all in the passages running from 29 to 33. They argued that Berkeley succeeded, at best, only in showing that "there [wa]s at least one mind other than Berkeley's" (Ksenjek and Flage 2012, 284-285 italics my own). Berkeley could show for certain neither the definite existence of one other mind grander than all others, single-handedly producing and organizing imprinted ideas, nor the existence of an entire host of other minds working together in the same task of imprinting ideas upon us (286). If Berkeley did make such a decision between these two options, Ksenjek and Flage $(2012,287)$ suggested that Berkeley might have done so by applying Ockham's Razor, to choose the simpler explanation where one mind orchestrated the order among ideas, and not many. That said, there was no textual evidence as to whether such a choice even crossed Berkeley's mind (287). This meant, as Ksenjek and Flage $(2012,293)$ aptly summed up,

"...even though Berkeley argued for the existence of the Judeo-Christian God, and even though he based his concept of God on Christian doctrine, this d[id] not entail that the Principles provide[d] a defense of a strictly Christian notion of God."

If we go further then to strip Berkeley's argument in passages 28 to 33 of any affinity with the Judeo-Christian God, we may say that Berkeley concluded in the following: that there existed "one finite mind... and one other mind of indeterminate power, although [its] power...[wa]s greater than that of the known finite mind" (Ksenjek and Flage 2012, 291). This "other mind" also needs not be $a$ mind. So long as the alternative "works", that is, these other minds imprint ideas constitutive of this world upon us and amount to something "more powerful" than our minds, we may say this host of other minds also serve in capacity as the Authors of Nature. I would like to take this interpretation by Ksenjek and Flage as my point of departure in my "reworking" of Berkeleyanism.

\section{3. "REWORKING” BERKELEYANISM FROM PRINCIPLES OF HUMAN KNOWLEDGE: THOSE OTHER MINDS "MORE POWERFUL" THAN ME}

Reworking Berkeleyanism is, of course, not a task I can claim to complete here, hence the quotation marks. The texts by Berkeley under consideration in this article are few in number, and I hope at best to offer a preliminary sketch of how Berkeleyanism might be reworked. I shall begin this section with an explanation of what it meant to call another mind or mind(s) "more powerful" in terms of the passages already quoted (2833), after which I would attempt to propose a Berkeleyanism "reworked" not around a single other mind but a host of other minds.

First, concerning what it means to call another mind or minds "more powerful" than my own: This phrase was used by Berkeley $(1967 \mathrm{~b}, 55)$ himself in passage 33 of Principles of Human Knowledge, to discern between the "thinking substance which perceive[d]" imprinted ideas and "another and more powerful spirit" imprinting ideas, with this "power" being expressed in the fact that imprinted ideas, being produced by 
the latter, were "less dependent" on the former. This much, of course, is already selfevident from passage 29 where Berkeley already established that some ideas were imprinted by us by another mind. Still, we may extract from here that to speak of another mind as being "more powerful" than our own is to speak of a certain "power" of this other mind, found in its imprinting of ideas upon us.

Now, obviously, our own minds are not lacking in the power of imprinting ideas upon others, but those ideas imprinted upon us by these other minds are unique in two regards: first, imprinted ideas exhibited, as Berkeley $(1967 \mathrm{~b}, 54)$ noted in passage 30, an orderliness ("a steadiness, order, and coherence...not excited at random") not to be found in ideas we excite by ourselves. This sufficed to testify, for Berkeley (54), to "the wisdom and benevolence of its Author".

We may say that the "wisdom" and "benevolence" of this other mind imprinting ideas upon us are testified in the uses we may set imprinted ideas to. For one instance, the order among imprinted ideas allowed us to learn from prior observations of successions of ideas. We learnt from experience that "food nourishe[d], sleep refreshe[d], and fire warm[ed] us" and, with this knowledge, we know to excite ideas by ourselves "to regulate our actions for the benefit of life", that is, to eat food for nourishment, to refresh us with sleep, and to warm ourselves with fire (Berkeley 1967b, $55)$.

This then brings us to a second difference between ideas imprinted upon us by other minds and ideas we excited by ourselves: that ideas we excite by ourselves are derivative of ideas imprinted upon us by other minds. This is also to say that imprinted ideas constituted the basis for and limits of ideas we might excite by ourselves. The "practical" uses mentioned above are only examples of this relation between our ideas and imprinted ones. Berkeley $(1967 b, 55)$ drew the following distinction between these two types of ideas,

"The ideas imprinted on the senses by the Author of Nature are called real things: and those excited in the imagination being less regular, vivid and constant, are more properly termed ideas, or images of things, which they copy and represent."

Imprinted ideas constitute "real things", whereas the relation of our ideas to these "real things" is understood to be strictly that of copying and representing. For one, a chimera, whose existence Berkeley $(1967 b, 56)$ granted insofar as we understood ideas of chimeras to be imagined and not real, would consist of a combination of copies of imprinted ideas constitutive of animal bodies. It is in this sense that ideas excited by us are derivative of ideas imprinted upon our senses by some other "more powerful" $\operatorname{mind}(\mathrm{s})$. This is also to say that some other "more powerful" mind(s) laid forth both the basis and the limits of those ideas we may excite by ourselves. This is the second meaning of saying that other minds are "more powerful" than our own. The "power" of other minds does not consist only of a superior "power" in producing and organizing ideas with an orderliness our minds cannot attain. We call other minds "powerful", since we depend on these other minds which have handed down to us the basis and limits of our own perceptual activities. 
If we think of the characterization of other minds as "more powerful" in this light, it might become clear why Ksenjek and Flage $(2012,287)$ wrote that, if Berkeley were presented with a choice between one mind orchestrating all imprinted ideas and numerous other minds, the former would prove the "simpler" option. Suppose we posit numerous other minds instead of one, we would no longer be certain that those minds imprinting ideas upon us are wise and benevolent. We would have to speculate instead on the relations between these numerous other minds and how these relations influence the ideas which are ultimately imprinted upon us. Would the order among imprinted ideas be the product of cooperation or competition among these other minds? The same goes for when we speak of our dependence upon other "more powerful" minds. In addition to the question already raised concerning the relations among posited other minds, we must also ask which mind it is that we are depending upon here, all of these other minds or only a few.

That said, I still think it necessary that we speculate here about the sort of Berkeleyanism we would have if we posit numerous other minds at work behind imprinted ideas instead of one. This speculation is, to my mind, necessary in order to account for our contemporary sensibilities whereby we recognize human and animal activities (i.e., the activities of finite minds) to hold some influence over the natural world. I would, specifically then, speculate here about the sort of Berkeleyanism we would have when we posit numerous finite other minds in the place of a singular Author of Nature.

Now, of course, Berkeley did not entertain the prospect of a reign of numerous other minds in Principles of Human Knowledge at all. In passage 30, only one passage after inferring that some other mind must exist which we might hold accountable for ideas not our own, Berkeley $(1967 \mathrm{~b}, 54)$ already began referring to the imprinting other mind as an "Author" in the singular. In order though to begin our speculations on solid ground, I would nevertheless like to draw upon remarks Berkeley might have made concerning the interactions between finite minds as a point of departure. To this end, I would like to look to Berkeley's political essay entitled Passive Obedience where Berkeley did just so, though in a chiefly negative light.

In Passive Obedience, we find Berkeley $(1967 \mathrm{c}, 22)$ establish first that "the general well-being of all men, of all nations, of all ages of the world" was an end to which human beings ought to aspire, after which he set up options of how this well-being might be attained. I am interested here in Berkeley's objection $(1967 \mathrm{c}, 22)$ to the first option he raised, whereby each human being would be allowed "to consult the public good, and always to do that which to him shall seem, in the present time and circumstances, most to conduce to it". To this, Berkeley (22-23) objected that,

"First...to calculate the events of each particular action is impossible; and, though it were not, would yet take up too much time to be of use in the affairs of life. Secondly... we can have no sure standard to which comparing the actions of another, we may pronounce them good or bad, virtues or vices...Every man's particular rule is buried in his own breast, invisible to all but himself, who therefore can only tell whether he observes it or no." 
This objection has a strong affinity with Berkeley's consideration of the "practical" uses we have for imprinted ideas in passage 31 of Principles of Human Knowledge. In this passage of the Principles, Berkeley $(1967 \mathrm{~b}, 55)$ spoke of our prior observations of order among imprinted ideas as affording us "a sort of foresight". "Foresight", of course, is also another way of saying that we knew what "outcome" would come after our actions (e.g., eating food, followed by the outcome of nourishment). In Passive Obedience, we may say Berkeley further explored the uses of this foresight in social life. The foresight of one human mind was limited and could not discern "all the hidden circumstances and consequences of an action" (Berkeley 1967c, 22). Berkeley (1967c, 23) also expanded upon his treatment of human perception in general and pointed out that perception would not reveal to us the particular standards for good and bad in another human mind, these standards being "buried in [the other's] breast" 6 . He concluded then that allowing finite human minds to pursue the well-being of humanity on their own would end in a lack of "harmony or agreement between the actions of good men", whereby "the best actions $\mathrm{m}$ [ight] be condemned, and the most villainous me[t] with applause" (Berkeley 1967c, 23). Now, we may say we have discovered here a hint of Berkeley's view of the relations among finite minds, at least within a moral context: the finite faculties of the human mind would make cooperation with one another difficult, since some ideas and notions (all circumstances and outcomes of all actions and the particular standards of good and bad) decisive of collective activities could not be known with our finite faculties.

Berkeley (1967c, 22), therefore, recommended in Passive Obedience the other option of pursuing the well-being of humanity, by "enjoining the observation of some determinate, established laws, which, if universally practised, ha[d], from the nature of things, an essential fitness to procure the well-being of mankind". Later on, Berkeley $(1967 \mathrm{c}, 26)$ also alluded to the formation of institutions which would serve to enforce ${ }^{7}$ these laws,

\footnotetext{
${ }^{6}$ Anita Avramides $(2000,130)$ has noted that while Berkeley appeared to have suggested that we might think, by analogy, of "another mind having similar ideas or notions" as us, but Avramides also noted that unless Berkeley could back this up with "an empirical claim about the way [our minds] [we]re similarly constructed, along with some principle to the effect that the same causes produce the same effects", Berkeley had no way of using ideas and notions in his mind "as the model for what [wa]s going on in another's mind" (132). We may think of Berkeley's contention that the particular rule dictating which particular idea would be morally right or wrong was "buried in [another's] own breast", was one of the instances when Berkeley pointed out explicitly the impossibility of knowing the ideas in the minds of another based on our own ideas. In simultaneity, we must say that Berkeley's consideration here was limited only to particular rules of right and wrong in each human mind. Avramides' critique still applies here, since Berkeley has not established any empirical claim showing a similar structure in our and others' minds, but also suggested here that the faculties of each mind would be as limited as the other.

${ }^{7}$ I say "enforce" here, since Berkeley (1967c, 24 italics removed) would argue later that these laws were derived "immediately from the Author of nature himself", as well as being "stamped on the mind, to be engraven on the tables of the heart, because they [we]re well known to mankind, and suggested and inculcated by conscience". Institutions or, specifically, the government was further held to be "the principal source under heaven of those particular advantages for the procurement and conservation whereof several unquestionable moral rules were prescribed to men" (Berkeley 1967c, 27). In other words, governments served for Berkeley, at best, to "enforce" moral rules already established by God.
} 
"The miseries inseparable from a state of anarchy are easily imagined. So insufficient is the wit or strength of any single man, either to avert the evils, or procure the blessings of life, and so apt are the wills of different persons to contradict and thwart each other, that it is absolutely necessary several independent powers be combined together, under the direction... of one and the same will, I mean the Law of the Society."

This passage might be read in relation to the passage quoted earlier. Those "miseries inseparable from a state of anarchy" Berkeley referred to here might be understood as the miseries consequent of human minds pursuing on their own, with their finite faculties, the well-being of humanity. If this is the case, we may say that the combination of otherwise independent human minds into "one and the same will" as "the Law of the Society" was as much a response to the miseries of a state of anarchy as a response to the finite faculties of human minds which caused those miseries in the first place. Human minds, which know neither all circumstances and consequences of their own actions nor the particular standards of good and bad in other minds, cannot be allowed to freely excite ideas on their own. Hence, these minds must be gathered together into an institution which would enforce laws to be followed by every mind involved in, or (in the case of a government) subordinated to, this institution.

Here I think we may transplant this progression from "a state of anarchy" into governmental rule from Passive Obedience into our reworked Berkeleyanism. I have noted already that Berkeley's own objection to trusting finite minds to pursue universal well-being on their own, had an affinity with Berkeley's $(1967 \mathrm{~b}, 55)$ discussion of "foresight" in passage 31 in Principles of Human Knowledge. The limited "foresight" and finite faculties of human minds in general cause those "miseries" Berkeley associated with "a state of anarchy". It would follow then the institutions formed from a state of anarchy are meant to "overcome" the finitude of human minds. This "overcoming" of finite faculties is achieved by enforcing pre-existent moral laws. That is to say, these institutions are responsible for producing and sustaining a certain order among ideas constitutive of our actions and outcomes of said actions, in obedience to pre-existent laws. These institutions served to prevent the miseries of anarchy whereby "the best actions may be condemned, and the most villainous me[t] with applause" (Berkeley 1967c, 23). In other words, these institutions served in a similar capacity as those other minds imprinting ideas upon us: they sustained order among ideas. That said, this order among ideas is given already and the institutions, much like particular finite minds, can never hope to surpass this order by setting up its own. More concretely, we may say that these institutions enforce the pre-existent order among ideas by establishing particular rules. Basic moral laws, such as "Thou shalt not forswear thyself', 'Thou shalt not commit adultery', 'Thou shalt not steal'", do not come with specific penalties, such as the jailtime the transgressor would have to serve, the manner of execution, among others (Berkeley 1967c, 26). All these would have to be supplied by those institutions enforcing these moral laws in particular rules.

This, to my mind, is a suitable framework within which we may begin speculating on the sort of Berkeleyanism we would be left with if we posit numerous finite other 
minds imprinting ideas upon us instead of one. What Berkeley has spoken of finite minds in general would be applied here on finite other minds ${ }^{8}$.

We may begin by positing, like those moral laws Berkeley posited, basic Laws of Nature, such as the laws of motion, thermodynamics, quantum mechanics, etc. which all finite other minds would be subjected to. We would take these Laws as brute facts so as not to call upon a God, gods, or some other mind(s) existent prior and superior to all finite minds to account for these Laws. The finite other minds living in conformity to Laws of Nature would form communes analogous to institutions enforcing moral laws, but these communes of finite other minds do not so much enforce the Laws of Nature as to, simply, make up for the finitude of one another's faculties. Particular rules are forwarded within these communes. Examples of these rules might be found in mutualistic and parasitic relations between humans and humans, animals and animals, human and animals. The cooperation between dogs, sheep, and shepherds operates by particular rules dictating that if the dogs do not attack, or harass in some other way, the sheep, the shepherds would not retaliate; and if the dogs go one step further to help guard the sheep, the shepherds would reward the dogs for their services. Since these particular rules are established by communes of human and animal minds, these particular rules are also susceptible to human and animal activities, even by the activities of those minds outside of the original communes which decided upon those rules. The historical domestication of sheep for wool and meat disrupted particular rules established prior between sheep and other undomesticated animals. The subsequent domestication of dogs as guards for the sheep and, later on, as pets also served to further disrupt pre-established rules. For another, we may look to human carbon emissions which aggravate global warming and, therefore, also disrupt the particular rules of avian migration set to take place under specific temperatures, weather conditions, etc. The totality of ideas excited by finite other minds in conformity to these particular rules and the Laws of Nature amounts to what we call the "natural world"

These finite other minds or, rather, the communes they form, therefore, serve in capacity as the "Author of Nature". Unlike the original "Author" in Berkeley's Principles of Human Knowledge where there was posited one mind "grander", "more powerful" than others, however, we must say here that each finite other mind is no

\footnotetext{
${ }^{8}$ See note 6 which has considered already Anita Avramides' critique of Berkeley for not justifying the similarity he presumed between our and others' minds, and how it might also pertain to Berkeley's reference to finite faculties of human minds in Passive Obedience. Hence, when I applied what Berkeley has spoken of finite human minds to finite other minds, I must confess to have presupposed, as Berkeley did in Passive Obedience, similar structures to our and others' minds. I can only defend this on two regards: first, that Berkeley's treatments of the relations between finite minds were premised upon this presupposed similar structure of mind and, hence, it is still functionally necessary to working within and expanding upon these relations between finite minds. Second, by the end of this section, I would show that it is the commune of these other minds which decides upon what ideas were imprinted upon our senses, such that whatever relations there are among these other minds are far less important than the "final decision" reached by these minds. Hence, the presupposed similarity in structure of finite minds is actually functionally insignificant, in that it does not have any actual impact on the conception of our experiences of having ideas imprinted upon us by "some" other mind(s), nor our dependence upon those ideas and those indeterminate "other minds" doing the imprinting.
} 
more or less "powerful" than us. After all, if not for their limited foresights and finite faculties in general, they would not have gathered into communes. It is the communes themselves to which we must attribute the power over us; that the communes are what are "more powerful" than us, not each finite other mind. We may think of our relations to these communes as analogous to our relations to parliamentary and other governmental bodies. Policies are devised through the collective efforts of those other minds working within these bodies and handed down to us. These policies, informed by the perceptions of the interests of multiple communities, would exhibit an "orderliness" or, at least, contain convoluted calculations of interconnecting interests which we cannot hope to complete by ourselves. These policies also organize those ideas constitutive of the basis for and the limits of our activities: our annual spending calculated in terms of the taxes demanded of us by governmental communes, our pursuits of pleasures limited in terms of what is legal, etc.

In a word, I have defined in this section, first, the meaning of calling another mind "more powerful" than us in the following way: first, the power of this mind or minds to produce and organize ideas into an order our own minds could not attain; and, second, the power to produce ideas which we must depend upon, as the basis and limits of our own perceptual activities. Second, I have speculated that if we are to posit in Berkeleyanism numerous other minds imprinting ideas upon us rather than one, then we may think of these numerous other minds as working in communes and establish particular rules dictating their own actions based on certain basic Laws of Nature. I have noted also that, under this "reworked" Berkeleyanism, we must characterize the communes as the ones which are "more powerful" than us, not particular finite other minds.

\section{NORINAGA: NOTHING-TO-DO (SEMUSUBENAKI) AND NOTHING-TO-BE-DONE (NASUSUBENAKI)}

As regards Motoori Norinaga, I would like to focus on Norinaga's treatment of the relation between a human and a god, with an emphasis on the term semusubenaki. Prior to this though, I would like to offer a brief overview of Norinaga's equivalent of Berkeley's other "more powerful" mind (or the "Author of Nature"), i.e., Norinaga's "gods" (kami). This would serve to establish, preliminarily, an alliance between Norinaga's Shinto-inspired cosmology and the "reworked" Berkeleyanism proposed in the previous section. In his forty-four-volume commentaries on the historical and mythical records, the Kojiki, Norinaga $(1930,140)$ wrote the following,

"...from the gods of heaven and earth found in the ancient chronicles, to those whose august spirits are enshrined in shrines, to human beings, birds, insects, trees, and grass the seas and the mountains... any being which is not common of this world, in possession of superior quality, and which inspires awe is called a god." 
If our aim here is introduce or, even, promote Norinaga's theology, we may certainly use this "functionalist" definition of a "god" as a gimmick. Since our aim here is secular, however, we may exploit this loose definition of a "god" to convert Norinaga's "gods" simply into "other "more powerful' beings", though not in the same sense as I have defined it in the previous section, since Norinaga's definition here referred to properties of those other beings themselves. In any case, we may still look to Norinaga's other remarks on his "gods" in a similar light. When Norinaga $(1991,31)$ held that "[e]verything in Heaven and Earth [wa]s in complete accordance with the will of the Gods", we may think of this as referring to the overlapping creative activities of these other "more powerful" beings, be it a human being holding socio-political power or a pack of wolves raiding human settlements, which culminated in every being and event in this world.

Norinaga referred to these creative activities by various terms, but, for terminological consistency, I would refer to these activities simply as "giving" $(\text { tamau })^{10}$. Now, these givings of beings and events by other "more powerful" beings were not always concomitant with one another. Norinaga believed in benign as well as malevolent "gods", as well as disparities of power among these beings ${ }^{11}$. Without delving into mythical accounts, we may say that Norinaga recognized conflicting natures in those other "more powerful" beings he posited, which would give way to

\footnotetext{
${ }^{9}$ This description of Norinaga's definition of a "god" was made by Ueda Kenji (2000).

${ }^{10}$ Tamau is not a term unique to Norinaga's writings at all. Norinaga $(1930,345)$ himself acknowledged that the word tamau could be used as "a mere word expressing worship" (agamekotoba). For the purpose of this paper, I refer to the use of tamau (as both verb and auxiliary verb) to refer, from the standpoint of someone of inferior standing, to a gesture from someone of superior standing in general, not only the gods. That said, under Norinaga's cosmology, "superiors" often coincided with the divine. The emperor of Japan was held to be a god, while the Tokugawa shogunate under which Norinaga lived was understood to rule Japan by the grace of the emperor and blessing of the gods (Motoori 1988, 55). Norinaga $(1930,56)$ also held that the professions each family took up were mere inheritances of the professions of these families' ancestral gods (oyakami). The relation of tamau in Norinaga to the divine (or other "more powerful" beings) resembled the relation of Berkeley's imprinting to God (another "more powerful" mind). "imprinting". That said, Norinaga being neither a rigorous empiricist nor an immaterialist like Berkeley, tamau clearly could not have been conceived, like "imprinting", as the giving of sensory ideas specifically.

The diverse accounts Norinaga provided of "giving" also complicated its meaning further. For one, in relation to the creation deities, the Musubi no Kami, Norinaga $(1930,146)$ used the term nariizuru ("to produce", also "to give birth to") to refer to their activities. He then cited, as examples of the "giving" of these gods at work, not only those beings and events brought about directly by these deities, but also myths where their offspring were involved. While we may understand this simply as Norinaga exploiting two meanings of nariizuru, he also made difficult a philosophical analysis of this term. Are we to think of the doings of a being's offspring as the doings of the parent itself? Was Norinaga allowing for a direct "secondary" cause (the offspring) to the indirect "primary" cause (the Musubi no Kami)? In any case, we may say that, unlike Berkeley who narrowed down the meaning of "imprinting", Norinaga's sense of "giving" was far more ambivalent.

${ }^{11}$ The sun goddess, Amaterasu no Ōmikami, which was also held to be the progenitor to the imperial family, was understood to be a god without whose favor "[n]o country c[ould] exist for a moment" (Motoori 1988, 47). Other gods were also entered into hierarchy after the sun goddess, with exceptional cases of "evil gods" whose malicious creative acts could attain an intensity even the sun goddess and other benign gods could not suppress (Motoori 1991, 33).
} 
cooperation or competition among these beings. If this is the case, we may say that these other "more powerful" beings operated within a "commune" of their own. This "commune" though would be distinct from the "commune" of finite other minds I spoke of in the previous section, which was established by finite minds to overcome their finite faculties. While, to be sure, Norinaga's "gods" did band together and operated in cooperation or competition, Norinaga would certainly yield to mythical accounts of the causes of why these beings gathered in the first place. Since he also defined these beings by their being uncommon, superior qualities, and power to inspire awe in us, it is dubious that he would allow for the characterization of the commune as that which was "more powerful" than us, and not the particular members of this commune instead. That said, Norinaga would still be partially agreeable to our "reworked" Berkeleyanism, if only on the fact that the world and the beings and events within are the results of overlapping and, sometimes, conflicting activities of beings other than us, which culminates in an orderliness we cannot hope to produce with our own finite powers, upon which we depend for the basis and limits of our own activities. At the same time, Norinaga's disagreement with us would consist of disagreements on the specific properties of those other beings whose activities culminated in our world and the beings and events within. This point of disagreement though does no harm to Norinaga's agreement with us. Whether we exalt each particular other being for being "more powerful" than us or exalt the commune of all other beings, the commune of other beings deciding upon the world and the beings and events within still stands. Hence, in addition to the alliance I shall establish between Bishop Berkeley and Norinaga, there exists also another alliance between my "reworked" Berkeley and Norinaga. I shall have cause to return to this at the end of this paper, but would like, for the moment, to let this alliance rest as it is.

Now, I would like to take a step back to Berkeley, specifically his account of our own experience of having this very world given to, or in Berkeley's terminologies, "imprinted upon" us. This would serve to draw out a major difference between Berkeley and Norinaga's treatment of other "more powerful" beings and minds not to be overlooked. Berkeley's example for imprinting can be found in passage 29 of Principles of Human Knowledge, where Berkeley $(1967 \mathrm{~b}, 54)$ spoke of how, when we opened our eyes in the day, it was "not in [our] power[s] to choose whether [we] shall see or no, or to determine what particular objects shall present themselves to [our] view[s]". Similar examples of beings and events being given to us in certain preestablished forms could also be found in Norinaga (1930, 9; italics my own),

"If you cleanse yourself of the heart corrupted by Chinese teachings and think carefully, you would realize that heaven and earth is merely heaven and earth, men and women is merely men and women, water and fire is merely water and fire. Though there is a certain form spontaneously attached to them, all of this is merely the doings of the gods. Therefore, any principle underpinning these forms must be miraculous and mysterious things, and not something human beings might know well."

This passage was written in opposition to the application of principles of yin, yang, and 
the five elements to the Kojiki, but this passage also offered us a glimpse of Norinaga's view that beings and events nevertheless were structured by others in a certain way. Unlike Berkeley though, Norinaga did not take this order among beings and events as his point of departure to infer that some other being or mind must exist which has produced this given order. If anything, it is not implausible that Norinaga would consider this inference a sign of "a heart corrupted by Chinese teachings", which would dare to account for the "doings of the gods" with human intellect. Norinaga (1930 4) also held that historical and mythical records such as the Kojiki were text unadulterated by Chinese meanings and, therefore, an authentic historical document, however outlandish its mythico-historical accounts might be. When the Kojiki spoke of the gods, their doings, and those descended from the gods, all of it would have to be taken to be true. Hence, Norinaga would have little to no cause in the first place to seek to establish further proof for the existences of the gods, and he might begin easily by simply taking the existences of the gods for granted. In other words, we may say that while Norinaga held, like Berkeley, that some manner of order was to be found among beings and events in the world, and this order was attributable to beings other and "more powerful" than us, he neither justified (logically) the leap to these other beings, nor moved further from this to infer anything concerning these other beings.

Did Norinaga offer us any other way of "knowing" the activities of these other "more powerful" beings? I would like to argue that, in the preface to the Kojiki-den entitled Naobi no Mitama, Norinaga offered just such a way. Since Norinaga held all beings and events to have been brought about by the "doings of the gods", it should be no surprise that even calamities and misfortunes, in general, would also be attributed to other "more powerful" beings and, specifically, malicious ones. In the preface to the Kojiki, Norinaga wrote the following concerning our relation to certain other "more powerful" beings which were malicious: "To our sorrow, nothing can be done [semusubenaku] about the violent perturbations of the evil Gods of Magatsubi" (Motoori 1991, 33).

This might appear a fairly insignificant remark blaming calamities and misfortunes on some evil force, but Sagara Tōru (1978) also saw the phrase "nothing can be done" as integral to Norinaga's thoughts. In fact, Sagara went so far as to make the phrase the title of the last division to his commentaries on Norinaga. The phrase itself became a hint for Sagara $(1978,209-223)$ to extract a "double structure" from Norinaga's writings: Norinaga's personal yearnings for a return to native Japanese roots were pitted against the customs in his lifetime which were heavily influenced by the foreign, especially Chinese, teachings. Sagara $(1978,223)$ argued that Norinaga resolved this opposition by submitting to these customs, while still holding onto the hope that "the fruits of his studies would be realized one day by the hands of those superior to him in standing".

Now, this treatment of the phrase "nothing can be done" (semusubenaki) was heavily influenced by Sagara's mentor, Watsuji Tetsurō, to which Sagara (1978, ix) admitted implicitly when he wrote that he was interested in "Norinaga the ningen" and the ethical thinking of Norinaga. Here, in this paper, however, I would like to consider the phrase semusubenaki more "literally", so to speak. While Sagara would have 
translated "gods" and those beings and events said "gods" gave into "social reality", I would translate the former only as "other "more powerful' beings" and preserve the latter as it is.

Concerning the term semusubenaki itself, sетu in semusubenaki is the modified form of $s u$ (roughly, "to do"). If we take it to express volition, then the most literal translation of semusubenaki would be "There is nothing I can think of doing", like an exclamation in a helpless situation. That said, it is also more than a "mere" exclamation. As we see in the remark in Naobi no Mitama where Norinaga $(1991,33)$ used this term, it is an exclamation coming after the experience of receiving certain beings and events from other "more powerful" beings, about which we could do nothing, hence giving way to the exclamation, "There is nothing I can do!" This, we may say after Sagara, is a crux of Norinaga's thoughts. We certainly see this confirmed in an unflattering comparison Norinaga $(1988,58)$ made of human beings to puppets,

"Let us say that the deities are like men and sacred matters are like the acts of men...let us say that humans are like puppets, and secular matters are like the movements of the puppets. These puppets have heads, arms, and legs, and their various movements occur because in actuality men manipulate them." 12

Instances of when human beings became analogous to puppets could be found not only in Norinaga's own experience of being a native studies thinker in a Japan heavily influenced by foreign teachings he had no hope of doing away with. In the case of events such as earthquakes, outbreaks, wars waged between nations, there is equally nothing for us to do (Nasusubenaki) which would not already have been done and completed by other "more powerful" beings. This holds true for Norinaga, as for us, whether we could think of something to do ourselves (semusube) or not. All of these were neatly summed up when Norinaga (Motoori, cited in Sagara 1978 234) wrote that "the becoming [naru], performance and completion [nasaru] of events were affairs human beings could not attain with their powers".

In other words, Norinaga's term semusubenaki could be understood as an expression of his recognition of a prior experience whereby everything was given by other "more powerful" beings, leaving nothing for him to do or complete with his own powers. I would like to denote this prior experience as Nasusubenaki (literally, "there is nothing to do"). Nasusubenaki may be understood in relation to Berkeley's theory of perception, as an experience which precedes the expression semusubenaki in succession. Nasusubenaki corresponds to a human experience which we perceive but not strongly. It is an ongoing experience consisting of us passively receiving from other "more powerful" beings successions of beings and events. So long as we perceive with our senses or are involved, in general, with something we cannot account for as our own creations, we are in the midst of the experience of Nasusubenaki. Semusubenaki,

${ }^{12}$ Sagara $(1978,231-236)$ also discussed this passage and made a point of arguing that this passage should not be read as a sign of determinism in Norinaga's thoughts (231) - an understandable move, since reading Norinaga as a determinist would undermine the dimension of the individual which Sagara aimed to preserve and hold in a triune opposition to "reality" and "reason" (ix). 
on the other hand, is an expression we use in response to very specific instances when the beings and events given are calamitous or contrary, in some measures, to habits we have formed, such as earthquakes, wars, outbreaks, and personal misfortunes. In these instances, we recognize that there is nothing we might do before the given calamities with our own powers and are thus compelled to say, "There is nothing I can do (semusubenashi)!"

For ease of reading, I shall also hereafter translate the expression semusubenashi hereafter simply as "nothing-to-do" and the experience nasusubenaki as "nothing-tobe-done".

\section{BERKELEY AND NORINAGA: AN ALLIANCE IN HAVING NOTHING TO BE DONE; NORINAGA AND THE “REWORKED” BERKELEY}

As a way of concluding this paper, I would like to open here with a comparison of Berkeley and Norinaga, after which I would move on to more speculative remarks on an alliance between the "reworked" Berkeleyanism presented in section 3 and Norinaga.

We may note first that both Berkeley and Norinaga emphasized on the experience of having certain beings and events or ideas given to oneself, which were ordered in a certain way and also served to lay the foundation and limits for one's subsequent activities. This experience, however, was not a point of departure in Norinaga for further demonstrations concerning those other "more powerful" beings which gave beings and events to us. This sets Norinaga apart from Berkeley whose argument for another "more powerful" mind depends upon this experience as its empirical basis, as we have seen in passage 29 of Principles of Human Knowledge. Where Berkeley aimed to argue causally for the existences of some other "more powerful" mind(s), Norinaga simply presupposed the existences of other "more powerful" beings. Consequently, the treatments of the human experience of given beings, events, and ideas by Berkeley and Norinaga also differ. For Norinaga, since the existences of the other "more powerful" beings were already presupposed, this experience of having beings and events given to oneself ("nothing-to-be-done") was thought on the basis of these presupposed other beings. This rendered Norinaga the exact opposite of Berkeley. Irrespective though of their approaches to other minds and beings and human experience, they nevertheless concluded in similar ontological frameworks whereby there must exist, other and "more powerful" than us, certain minds or beings.

Their agreement over the existences of other "more powerful" minds or beings is also bound up with another agreement of theirs over the "natures" of that experience where we receive beings, events, and ideas from other minds or beings. I have already spoken in the previous section of this experience as that of there being "nothing-to-bedone" (Nasusubenaki). Within Norinaga's writings, we see this experience illustrated chiefly through its relation to the expression, "There is nothing I can do (semusubenashi)!", elicited only when given beings and events are contrary to our interests. Within Berkeley's writings, however, we find a more ordinary example. In passage 29 of Principles of Human Knowledge, Berkeley (1967b, 54) cited the everyday experience of opening our eyes in daylight and pointed out the obvious here: 
that it was never "in [our] power[s] to choose whether [we] shall see or no, or to determine what particular objects shall present themselves to [our] view[s]". However self-evident this might appear to be, it is worth noting that Berkeley, like Norinaga, emphasized upon the lack of power to "choose" and "determine" what was imprinted upon our senses. It is certainly not inconceivable that this same lack of power, in the case of ideas far more contrary to our interests, would itself become a cause for suffering and elicit from Berkeley, as from Norinaga, the exclamation of "There is nothing I can do!" We may think then of the experience of opening our eyes in daylight as one of the exemplary experiences of "nothing-to-be-done": the calm and, even, inconspicuous receiving of ideas from some other "more powerful" minds, sometimes interrupted by exclamations of "There is nothing I can do!" when we come across a dead squirrel on the road or a car accident.

In a word, Berkeley and Norinaga concurred on the following two points:

1. That we are constantly receive certain beings, events, and ideas given to or imprinted upon us by other beings or minds. These beings, events, and ideas are ordered in a certain way and constitute the basis and limits of our activities. There is also nothing we might do in relation to these beings, events, and ideas.

2. If said beings, events, and ideas are given to us by another being or mind, this other being or mind must be "more powerful" than us. "More powerful" here means, first, that these other beings or minds are responsible for the production of the order among beings, events, and ideas we cannot hope to accomplish with our own limited powers; and, second, that we depend upon those beings or minds for the basis and limits of our own activities.

On the issue of other minds and beings, and our relations to said minds and beings, I suspect it would be difficult to push for further semblance between the original Berkeley and Norinaga. To do so would require us to look into the properties Berkeley and Norinaga attributed to other minds and beings, which would not only enter us into theology, but also compel us to navigate historical, cultural, etc. relations between Judeo-Christian monotheism and Shinto polytheism. That said, Margaret Atherton and Helen Yetter-Chappell have shown that the Judeo-Christian God could be done away with from Berkeleyanism. Ekaterina Ksenjek and Daniel Flage have also shown that Berkeleyanism was "open-ended" when it came to the question of other minds. If those two points of agreement between Berkeley and Norinaga I have listed above do not posit, unbeknownst to me, any property of other minds and beings other than those knowable to us in the experience of "nothing-to-be-done", then we may say that we are standing now at the same brink Berkeley stood on in passage 29 of Principles of Human Knowledge. We know that there exist "some other will or spirit that produces" those beings, events, and ideas unaccountable as our own and constitutive of this world. We remain at liberty to choose between another mind in the singular orchestrating all imprinted ideas, and numerous other minds.

In choosing the latter then, we would find ourselves thrown back to section 3 of this paper and the Berkeleyanism "reworked" in that section. I have also noted in the opening of section 4 that Norinaga would be partially agreeable to our "reworked" Berkeleyanism on the positing of a commune of other minds or beings, while 
disagreeing with us on the specific properties of these other beings. I have noted also that Norinaga's disagreement with us could do no harm to where he would agree with us, since the commune of other minds or beings would still stand irrespective of our speculations into the properties of its members. This means that the experience of having ideas imprinted upon us, or beings and events given to us - that is, the experience of "nothing-to-be-done"-likewise still stands. Therefore, we may also retrofit the two points Berkeley and Norinaga agreed over into the Berkeleyanism we have "reworked" by positing communes of numerous finite other minds imprinting ideas upon us in the place of a singular mind.

We may now say, in this "reworked" Berkeleyanism, as we have with the original Berkeley and Norinaga, that that there is nothing we can do before those "more powerful" communes of finite other minds which pass down to us particular rules. These particular rules and the imprinted ideas obeying these rules form the basis and limits of our activities which we may neither do without nor transcend.

This much would already be obvious, and it is here that Norinaga's clarification of the experience of ideas imprinted upon us as "nothing-to-be-done" would compel us to look at our relation to these communes of other minds or beings in a new light. If previously we have accepted our lack of power in choosing whether we can see or not and what objects we see without much thought, this lack of power now stands out as something prevalent in every moment of our being. We find ourselves in constant subordination to other "more powerful" minds or beings. Even in a secular age such as ours, finite other minds, formerly our kin in the shared finitude of our faculties, would set themselves up as small despots within institutions of their own and unfold a dictatorship over us which goes unnoticed except when their decisions begin to cut into our livelihoods. For one instance, we may consider our relations to corporations and governments whose members might have contributed extensively to aggravating ongoing ecological, financial, political, etc. crises., about which we can do scarcely anything. Worse yet, those decisions made by these communes also form the basis and limits for our own activities and enter us into complicity with the very communes whose decisions we have no sway over. We are plunged then into a circle of escalating miseries with no hope of leaving via our own finite powers. The rights still reserved for us appear to only be that of expressing our despair with the cry, "There is nothing I can do!", or to hope, optimistically, that those communes would be reformed from within by some finite other mind.

A question might now also present itself: if both a Berkeleyanism which posits a singular divine other mind and a commune of finite other minds leave us equally with nothing to be done, should we not begin to look for an alternative which makes do without establishing between us and other minds or beings an unreconcilable disparity of power? We may begin to question, for one, the progression Berkeley $(1967 \mathrm{c}, 26)$ posited in Passive Obedience from a state of anarchy to the formation of institutions ${ }^{13}$ :

\footnotetext{
${ }^{13}$ Berkeley (1967c, 32) has defended this progression by claiming that human minds had "a natural tendency or disposition to a social life", which was also what "necessarily result[ed] from the differences which distinguish man from beast".
} 
what if we attempt to conceive of a Berkeleyanism centered, first and foremost, around this original state of anarchy and not its dissolution under institutions? Or, even, more radically still, a Berkeleyanism which refuses altogether to move beyond the state of anarchy? Would this place us back on equal footing with finite other minds, each being as short-sighted as the other? To be sure though, this question and this alternative, among many other alternatives we may still propose, all lie beyond the scope of this essay.

\section{ACKNOWLEDGEMENTS}

The author would like to thank the journal editorial team and an anonymous referee whose comments and suggestions contributed immensely to improve this paper.

\section{REFERENCES}

Antoni, Klaus (2004), "Karagokoro: Opposing the 'Chinese Spirit': on the Nativistic Roots of Japanese Fascism", in Bruce Reynolds (ed.), Japan in the Fascist Era (New York: Palgrave Macmillan), 49-72.

Atherton, Margaret (1995), "Berkeley without God", in Robert G. Muehlmann (ed.), Berkeley's Metaphysics: Structural, Interpretive, and Critical Essays (Pennsylvania State University Press), 231-248.

Avramides, Anita (2000), "Berkeley and knowledge of other finite spirits", in Other Minds (London: Routledge), 113-136.

Berkeley, George (1967a), "An Essay towards a New Theory of Vision", in Works of George Berkeley, Bishop of Cloyne, Volume 1 (London: Thomas Nelsons \& Sons Ltd.), 161-241.

Berkeley, George (1967b), "A Treatise Concerning the Principles of Human Knowledge", in Works of George Berkeley, Bishop of Cloyne, Volume 2 (London: Thomas Nelsons \& Sons Ltd.), 22-115.

Berkeley, George (1967c), "Passive Obedience", in Works of George Berkeley, Bishop of Cloyne, Volume 6 (London: Thomas Nelsons \& Sons Ltd.), 15-47.

Charles, Sébastien (2010), "The Animal according to George Berkeley", in Silva Farigi (ed.), George Berkeley: Religion and Science in the Age of Enlightenment (Springer Science \& Business Media), 189-199.

Flage, Daniel E. (1985), "Berkeley's Notions", Philosophy and Phenomenological Research 45. 3: 407-425.

Isomae, Jun'ichi (2000), "Reappropriating the Japanese Myths: Motoori Norinaga and the Creation Myths of the Kojiki and Nihon Shoki", Japanese Journal of Religious Studies 27.1-2: 15-39.

Kamata, Tōji (2009), "Monogaku no Kōchiku [The Construction of Monogaku]”, in Tōji Kamata (eds), Monogaku no Bōken [The adventures of Monogaku] (Tokyo: Sogensha), 5-28. 
Ksenjek, Ekaterina Y. and Daniel E. Flage (2012), "Berkeley, the Author of Nature, and the Judeo-Christian God", History of Philosophy Quarterly 29: 3: 281-299.

Motoori, Norinaga, (1930), Kokun Kojiki-den Dai-ichi [Kojiki-den in old writing system Volume 1] ed. Takeo Mukōyama (Nihon meicho kankō-kai).

Motoori, Norinaga (1988), "Tamakushige", Monumenta Nipponica 43.1: 45-61.

Motoori, Norinaga (1991), "The Way of the Gods. Motoori Norinaga's Naobi no Mitama", trans. Sey Nishimura, Monumenta Nipponica 46.1: 21-41.

Sagara, Tōru (1978). Motoori Norinaga (Tokyo: Tokyo University Press).

Ueda, Kenji, Havens, Norman (trans.) (2000), "Magatsubi no Kami and Motoori Norinaga's Theology", Contemporary Papers on Japanese Religion. < https:// www2.kokugakuin.ac.jp/ijcc/wp/cpjr/kami/ueda.html>

Yetter-Chappell, Helen (2017), "Idealism without God", in Goldschmidt Tyron and Kenneth Pearce (eds), Idealism: New Essays in Metaphysics (Oxford University Press), 67-82. 